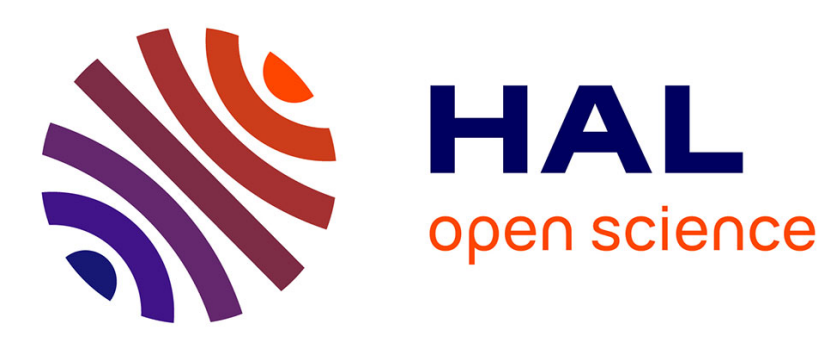

\title{
Sound-induced motion in chimpanzees does not imply shared ancestry for music or dance
}

Mila Bertolo, Manvir Singh, Samuel Mehr

\section{To cite this version:}

Mila Bertolo, Manvir Singh, Samuel Mehr. Sound-induced motion in chimpanzees does not imply shared ancestry for music or dance. Proceedings of the National Academy of Sciences of the United States of America, 2021, vol. 118 ( $\left.\mathrm{n}^{\circ} 2\right)$. hal-03268513

\section{HAL Id: hal-03268513 \\ https://hal.science/hal-03268513}

Submitted on 23 Jun 2021

HAL is a multi-disciplinary open access archive for the deposit and dissemination of scientific research documents, whether they are published or not. The documents may come from teaching and research institutions in France or abroad, or from public or private research centers.
L'archive ouverte pluridisciplinaire HAL, est destinée au dépôt et à la diffusion de documents scientifiques de niveau recherche, publiés ou non, émanant des établissements d'enseignement et de recherche français ou étrangers, des laboratoires publics ou privés. 


\title{
Sound-induced motion in chimpanzees does not imply shared ancestry for music or dance
}

\author{
Mila Bertolo ${ }^{a, 1}$, Manvir Singh ${ }^{b, c} \mathbb{C}_{(}$, and Samuel A. Mehr ${ }^{a, d, e, 1}(\mathbb{C}$
}

Hattori and Tomonaga (1) report that seven captive chimpanzees moved in response to piano sounds, more so than in silence. On this basis, they argue, "some biological foundation for dancing existed in the common ancestor of humans and chimpanzees 6 million years ago."

Music's universality suggests it has deep phylogenetic roots (2). Understanding music-like behavior in nonhuman animals is therefore valuable for understanding the evolution of music (3). But such a claim of shared ancestry for music or dance is unjustified, for three reasons.

First, the effects were heterogenous across a small sample (1). The most active chimpanzee (Akira) moved more than 50 times longer than the least active chimpanzee. Such dramatic variability challenges conclusions about species-wide typicality. This is further complicated by the chimpanzees' prior experience, in pilot experiments, with the same rhythmic patterns in other timbres (sounds the chimpanzees apparently found aversive; see ref. 1, p. 937).

Second, the chimpanzees did not entrain to the beat (1), a signature of rhythm perception (4) that has evolved in many species (5). Akira moved comparably when the rhythms were randomized (obscuring the beat) and when the sounds were more obviously rhythmic. The motion thus had little to do with musical rhythm, complicating generalizations about the evolution of music. A control condition testing whether chimpanzees respond less to nonmusical sounds (e.g., white noise, natural sounds matched in arousal levels) and/or jittered rhythms, as in prior research (4), could determine whether the motion is indeed attributable to music qua music. But Akira's behavior suggests it would fail.

Third, nonhuman primates often sway in response to arousing or aversive stimuli. Chimpanzees sway not only when they hear piano sounds (1) but also when deprived of food, when given amphetamines, and when subjected to bursts of loud white noise (6). Captive gibbons and sooty mangabeys display similar behaviors during increases in arousal $(7,8)$. That the chimpanzees swayed in response to piano sounds may reflect a general response to arousing stimuli rather than a musical behavior.

Akira did choose to spend time near the sound's source, suggesting a preference for it (1). But the enclosure made it impossible to escape the sound; and interest in a stimulus does not imply a preference for it. Moreover, music is not necessarily appealing to nonhumans, as auditory preferences differ across primate species. Tamarins show no preference between a screeching fingernails-on-chalkboard sound, which is highly aversive to humans, and amplitude-matched white noise (9). When offered a choice between two stimulus types, tamarins and marmosets preferred silence over music (10). The chimpanzees in ref. 1 may similarly have preferred silence to the sounds (e.g., if they found them arousing or aversive), but their preferences were not measured.

Future experiments that isolate bona fide musicspecific preferences and responses in nonhuman primates, consistently across individuals, would clarify whether and how these results bear on the evolution of musicality. Until then, an alternative explanation is that some chimpanzees find some sounds aversive or arousing, leading them to move more, via a mechanism unrelated to the evolution of musicality.

\section{Acknowledgments}

M.B. and S.A.M. are supported by NIH DP5OD024566. S.A.M. is supported by the Harvard Data Science Initiative. M.S. is supported through IAST by the French National Research Agency/ANR under the Investments for the Future/Investissements d'Avenir program (ANR-17-EURE-0010).

\footnotetext{
a Department of Psychology, Harvard University, Cambridge, MA 02138; bepartment of Human Evolutionary Biology, Harvard University, Cambridge, MA 02138; ' Institute for Advanced Study in Toulouse (IAST), 31080 Toulouse Cedex 6, France; ${ }^{d}$ Data Science Initiative, Harvard University, Cambridge, MA 02138; and 'School of Psychology, Victoria University of Wellington, Wellington 6012, New Zealand Author contributions: M.B., M.S., and S.A.M. wrote the paper.

The authors declare no competing interest.

Published under the PNAS license.

${ }^{1}$ To whom correspondence may be addressed. Email: sam@wjh.harvard.edu or mila_bertolo@g.harvard.edu.

Published December 22, 2020.
} 
1 Y. Hattori, M. Tomonaga, Rhythmic swaying induced by sound in chimpanzees (Pan troglodytes). Proc. Natl. Acad. Sci. U.S.A. 117, 936-942 (2020).

2 S. A. Mehr et al., Universality and diversity in human song. Science 366, 957-970 (2019).

3 S. A. Mehr, M. M. Krasnow, G. A. Bryant, E. H. Hagen, Origins of music in credible signaling. Behav. Brain Sci., 10.1017/S0140525X20000345 (2020).

$4 \mathrm{H}$. Honing, F. L. Bouwer, L. Prado, H. Merchant, Rhesus monkeys (Macaca mulatta) sense isochrony in rhythm, but not the beat: Additional support for the gradual audiomotor evolution hypothesis. Front. Neurosci. 12, 475 (2018).

5 M. Wilson, P. F. Cook, Rhythmic entrainment: Why humans want to, fireflies can't help it, pet birds try, and sea lions have to be bribed. Psychon. Bull. Rev. 23, 1647-1659 (2016).

6 G. Berkson, W. A. Mason, Stereotyped behaviors of chimpanzees: Relation to general arousal and alternative activities. Percept. Mot. Skills 19, 635-662 (1964).

7 S. M. Cheyne, Unusual behaviour of captive-raised gibbons: Implications for welfare. Primates 47, $322-326$ (2006).

8 J. Crast, M. Bloomsmith, J. Perlman, T. Meeker, C. Remillard, Abnormal behaviour in captive sooty mangabeys. Anim. Welf. 23, 167-177 (2014).

9 J. McDermott, M. D. Hauser, Are consonant intervals music to their ears? Spontaneous acoustic preferences in a nonhuman primate. Cognition 94, B11-B21 (2004).

10 J. McDermott, M. D. Hauser, Nonhuman primates prefer slow tempos but dislike music overall. Cognition 104, 654-668 (2007). 